1 Title: Hybridization potential between Amaranthus tuberculatus and Amaranthus albus

2

3 Authors: Brent P Murphy, Laura A Chatham, Danielle M McCormick, Patrick J Tranel

4

5 Affiliations: Department of Crop Sciences, University of Illinois, Urbana, Illinois, USA

6

7 Corresponding author: Patrick J Tranel (tranel@illinois.edu) 1201 W. Gregory Dr., Urbana, IL

$8 \quad 61801$

9

10 Running title: Hybridization of A. tuberculatus and A. albus

11

12 Keywords: Amaranthus tuberculatus, Amaranthus albus, interspecific hybridization, apomixis,

13 auto-pollination,

14

15 Word count: 3,020

16 Number of figures: 1

17 Number of tables: 3

18 List of online appendix items: Supplementary Figure 1, Supplementary Figure 2 
Abstract

The genus Amaranthus is composed of numerous annual herbs, several of which are primary driver weeds within annual production agricultural systems. In particular, Amaranthus tuberculatus, a

22 dioecious species, is noteworthy for rapid growth rates, high fecundity, and an expanding geographic distribution. Interspecific hybridization within and between the subgenera Amaranthus and Acnidia is reported both in controlled environment and field studies, however a gap in knowledge exists with the subgenus Albersia. Interspecific hybridization may contribute to genetic diversity, and may contribute to the current range expansion of A. tuberculatus. Recently, a herbicide resistance survey of A. tuberculatus across five Midwestern states reported alleles of PPX2 similar to sequences of Amaranthus albus, a monoecious species. Here, we seek to generate empirical data for the hybridization potential of A. albus and A. tuberculatus through replicated, controlled crosses in a greenhouse. Of 65,000 progeny screened from A. albus grown with $A$.

31 tuberculatus males, three were confirmed as hybrids. Hybrids were dioecious, possessed 32 phenotypic traits of both species, and had limited to no fertility. DNA content analysis of backcross progeny suggested a polyploid state may be required for hybrid formation. Screening of 120 progeny of A. tuberculatus females grown with A. albus identified no hybrids, though a skew to female progeny was observed. The female skew may be due to apomixis or auto-pollination, the spontaneous generation of male flowers on otherwise female plants. Our results indicate that

37 introgression between A. albus and A. tuberculatus will occur less frequently than what has often been reported from hybridization studies with different pairs of Amaranthus species. 
Introduction

41 The genus Amaranthus is composed of numerous successful annual herbs of ruderal habitats.

42 Amaranthus species are globally distributed, and several have naturalized throughout the world as

43 a result of human-mediated seed flow (Sauer 1967). While much of the interest in the genus is a

44 result of the prevalence and impact of certain species on agricultural production, they are also

45 important components of native ecosystems (Steckel et al. 2004; Culpepper et al. 2006; Tranel et and A. palmeri are particularly noteworthy (Tranel et al. 2011; Ward et al. 2013). These two species are both dioecious and they possess rapid growth rates, high fecundity, and expanding ranges. The factors that facilitate the expansion of these species have not been fully characterized, though range expansion is likely facilitated by herbicide resistance traits evolved within these species.

A primary selection pressure within conventional croplands is herbicides. For example, Benbrook (2016) predicted that in 2014, the total use of glyphosate within the US corresponded to $1 \mathrm{~kg}$ ae

$54 \mathrm{ha}^{-1}$ of cropland within the country. In contrast, a typical field use rate for a single application can

55 be considered to be $840 \mathrm{~g}$ ae ha $\mathrm{ha}^{-1}$, equating to over one labelled application per hectare cropland

56 (Murphy et al. 2019). The establishment of resistant populations may both exclude native species

57 from these habitats, and also provide a source of resistance traits to related species through

58 hybridization. Furthermore, gene flow from these native, related species may transfer adaptive traits to the invading plants, facilitating establishment and local adaptation (Arnold 2004; Suarez-

Gonzalez et al. 2018). Therefore, the adaptive potential of the gene pool, not simply a species, must be considered to predict range expansions. 
63 Considerable genetic diversity exists within the Amaranthus genus, as illustrated by the naturalized

64 range of member species. Amaranthus retroflexus is perhaps the most widely distributed, where

65 the species is considered naturalized world-wide (Sauer 1967). However, most Amaranths inhabit a more narrow range. Amaranthus tuberculatus was historically confined to the American Midwest

67 and Mississippi River basin (Costea et al. 2005). However, recent expansions of weedy biotypes invasion of a given biotype and the adaptive introgression of weedy traits into native, largely nonweedy genepools (Milani et al. 2020; Kreiner et al. 2019).

72 Hybridization across species boundaries is well documented within Amaranthus. A pertinent 73 example is glyphosate resistant Amaranthus spinosus observed in Mississippi (Nandula et al. 74 2014). Hybridization with A. palmeri allowed the transfer and introgression of the glyphosate 75 resistance trait into $A$. spinosus. While modern phylogenies place A. palmeri and A. spinosus as 76 neighbors, hybridization within Amaranthus does not appear to be precluded even outside 77 subgenera. Several studies have documented the hybridization potential and frequency between

78 phylogenetically divergent Amaranthus species. For instance, the hybridization rate of A. palmeri 79 and A. tuberculatus, each members of the two clades of the subgenera Acnidia, was observed at low frequencies both under controlled environments and field conditions (Franssen et al. 2001;

81 Oliveira et al. 2018). In contrast, hybridization between A. tuberculatus and Amaranthus hybridus, 82 a member of the subgenera Amaranthus and putative progenitor of the cultivated Amaranthus hypochondriacus, was observed at high frequencies under both greenhouse and field conditions 
84 (Trucco et al. 2005, 2009). Further observations of interspecific hybridization within Amaranthus

85

86

87 A notable gap is observed in the case of the subgenera Albersia, to which the weedy species are reviewed by Trucco and Tranel (2011).

Amaranthus albus is a member (Stetter and Schmid 2017). No interspecific hybridization studies have been conducted with Albersia. However, support for gene flow between members of Albersia and Acnidia exist. A survey of resistance to herbicides that inhibit protoporphyrinogen oxidase in A. tuberculatus from five Midwestern states reported alleles of PPX2 similar to sequences of $A$. albus (Nie et al. 2019). Indeed, both species are regarded as abundant weeds within the surveyed region. Plants that possessed these sequences were associated with more western sampling locations and states, where A. albus is expected to be more frequent. However, the frequency of interspecific hybridization between $A$. albus and A. tuberculatus is unknown. Here, we report on the hybridization potential of A. albus and A. tuberculatus from controlled greenhouse crosses, as measured through hybridization frequency and hybrid fecundity.

Materials and Methods

Population generation

The A. tuberculatus population PI 654437 and an in-house A. albus population were selected for this study. PI6554437 possesses resistance to acetolactate synthase (ALS) inhibitors, a highly heritable and selectable marker, mediated through a single amino acid substitution (W574L) in ALS (Patzoldt et al. 2005; Patzoldt and Tranel 2007). The A. albus population was phenotypically 
sensitive to imazethapyr (an ALS-inhibiting herbicide; data not shown). Reciprocal crosses were conducted between the two populations under Delnet pollen containment tents (SWM, Georgia, USA) in separate greenhouse rooms during the winter months (to limit the potential for external pollen contamination). Plants were grown under 12:12 day:night cycle, with temperature ranging from 28 to $30 \mathrm{C}$ during the day and 25 to $27 \mathrm{C}$ during the night in 1:1:1 soil:peat:torpedo sand mix. As A. tuberculatus is dioecious, pollen competition can be minimized through plant selection. However, A. albus is monoecious and can produce over 100,000 flowers in an indeterminate fashion; hence, seed collected from A. albus plants was produced under a pollen competitive environment. A total of eight A. albus x A. tuberculatus crosses were conducted across two pollination tents to obtain $A$. albus progeny, and four crosses conducted in four tents to obtain $A$. tuberculatus progeny. At maturity, plants were allowed to dry and seed obtained by manual threshing. To increase germination, seeds were surface sterilized with $50 \%$ fresh bleach, washed with deionized sterile water, and suspended in $0.1 \%$ agarose for five weeks at $4 \mathrm{C}$.

\section{Hybrid screening}

\section{Putative hybrid identification:}

Seeds derived from eight $A$. albus plants were screened for resistance to imazethapyr at a density of 39 viable seeds $\mathrm{cm}^{-2}$. Density was determined by seed weight, and the number of viable seeds was calculated based on percent germination obtained on moistened filter paper in petri dishes. Seeds were sown in growth medium (1:1:1 mixture of soil, peat, and sand) and $360 \mathrm{~g}$ imazethapyr $\mathrm{ha}^{-1}$ (Pursuit; BASF) was applied immediately after planting. Applications were made with a moving-nozzle cabinet spray chamber using an 80015 even flat fan nozzle (TeeJet Technologies), 
130 with spray volume calibrated for $187 \mathrm{~L} \mathrm{ha}^{-1}$ applied $46 \mathrm{~cm}$ above the soil surface. After herbicide

131 application, flats were incubated under the same greenhouse conditions described above. Surviving

132 plants were classified as putative hybrids. Seed derived from A. tuberculatus female plants were

133 classified as putative hybrids because they were produced in tents lacking male A. tuberculatus

134 plants and a strong selectable marker for the A. albus parent was not available.

Hybrid validation

Putative hybrids were screened with restriction fragment length polymorphisms (RFLPs) that delimit between A. albus and A. tuberculatus (Wetzel et al. 1999). The expected digest patterns

140 for each species and their hybrids are described in Table 1. Briefly, DNA was extracted following

141 a CTAB procedure and diluted to $50 \mathrm{ng} \mathrm{uL}^{-1}$ with spectrophotometry (NanoDrop 1000

142 Spectrophotometer; Thermo Fisher Scientific) (Patzoldt and Tranel 2007). RFLP assay was 143 conducted following Wetzel et al. (1999), and imaged on a 2\% agarose gel stained with GreenGlo 144 Safe DNA Dye. Banding patterns were assessed visually to validate hybrids.

148 Validated hybrids were phenotyped and backcrossed to A. tuberculatus PI 654437 to test hybrid 149 fertility. $\mathrm{BC}_{1}$ plants were grown to the reproductive stage and tissue taken for DNA content 150 analysis. Three floral branches per individual were harvested and stripped of floral tissue. Nuclei 151 isolation and flow cytometry were conducted as described by Rayburn et al. (2005) with the 152 following modifications: maize hybrid VT3 was used as an internal standard for each sample, and 
153 peak area was calculated with FCS Express software. Hybrids were phenotyped and fecundity

154 measured through backcrosses to PI 654437. Fertility was determined through visual observation

155 of seed production at maturity.

157 Results

Hybrids from A. albus as maternal parent

Eighty-six thousand seeds by weight equally derived from the eight $A$. albus parent plants were screened to identify putative hybrids. These populations possessed an average germination frequency of $75.3 \%$, resulting in nearly 65,000 viable seed screened. A total of 13 survivors from the imazethapyr application were obtained, and screened with molecular markers. Three of these 13 survivors were identified as true hybrids (Figure 1), resulting in a hybridization frequency of $0.0046 \%$.

The morphologies of mature hybrids are shown in Supplementary Figure 2. A varying degree of 
176 sterile and produced no seed. HY2F was mostly sterile, though over 100 seeds were obtained from

177 backcrosses to PI 654437. HY3M was male, and appeared to dehisce pollen, though no

178 backcrosses were conducted due to plant staging errors.

179

Similar to the initial hybrids, the $\mathrm{BC}_{1}$ plants derived from $\mathrm{HY} 2 \mathrm{~F}$ were dioecious but otherwise possessed morphological characteristics of both parents, as shown in Supplementary Figure 3. The

$\mathrm{BC}_{1}$ plants exhibited a higher degree of branching than is typically observed in A. tuberculatus.

183 Curiously, leaves occurred throughout the terminal inflorescence. While this trait is characteristic of $A$. albus, which possesses no true terminal inflorescence, this was not observed within HY2F.

All plants appeared sterile, or possessed very limited seed set (tens of seed per female). DNA content analysis revealed that all tested hybrid progeny possessed DNA contents greater than tetraploid.

Hybrids from A. tuberculatus as maternal parent

192 Screening of 120 seeds with the RFLP markers from the four A. tuberculatus female plants yielded 193 no confirmed hybrids. Seed production of each plant was minimal, with yields ranging from tens 194 to low hundreds of seeds produced, whereas tens to hundreds of thousands of seeds are expected 195 when pollinated by an A. tuberculatus male. Progeny were grown to maturity and gender ratios 196 calculated through visual assessment. Only 16 of the 120 plants were males, whereas progeny from 197 PI 6354437 exposed to A. tuberculatus pollen were equally divided between males and females 198 (Table 3). 
Discussion

201

Three hybrids between A. albus and A. tuberculatus were successfully identified. The rate of other interspecific crosses conducted within the genus. Crosses conducted between representatives palmeri (Stetter and Schmid 2017), and A. albus has a matching chromosome number to $A$. tuberculatus $(2 \mathrm{~N}=32)$, while $A$. palmeri does not $(2 \mathrm{~N}=34)$ (Grant 1959). Nevertheless, major

211 fertility issues were observed both within the initial hybrids as well as in the $\mathrm{BC}_{1}$ population. These

212 results suggest that, while the cross can happen, A. tuberculatus is not within the primary gene

213 pool of A. albus. Furthermore, flow cytology suggests that elevated DNA content was observed 214 within the $\mathrm{BC}_{1}$ population. Perhaps a polyploid state is necessary to produce hybrids between $A$.

218 hybridization frequencies. 
222 (Trucco et al. 2005). Apical dominance was observed in all hybrids during the vegetative stage,

223 though this dominance weakened during the reproductive stage. As such, apical dominance

224 appears dominant over the extensive lateral branching pattern of A. albus, which results in its

225 "tumbleweed" morphology. Stem color was variable amongst hybrids, an indication that traits

226 from both parents were expressed within the hybrid plants.

227

228

229

230

231

232

233

234

235

236

237

238

239

240

241

242

243

244

While theoretically possible, the low frequency of hybridization and the low frequency of fecundity across multiple generations suggests that $A$. albus is unlikely to contribute adaptive traits towards the expansion of $A$. tuberculatus. However, herbicide resistance traits could provide a qualitative fitness advantage to overcome these boundaries within agricultural systems. There is no reported case of herbicide resistance in A. albus within the continental US (Heap 2020). The origin of the 'tumble-type' PPX2 allele observed by Nie et al. (2019) remains unresolved, but could indicate that even extremely low rates of hybridization and low viability of hybrids is still sufficient to allow gene introgression between these two species. Of the member species of Albersia, only A. albus and Amaranthus blitoides are considered agronomically important weeds in American Midwest, though neither is noted for herbicide resistance. An alternative is that the observed allele simply evolved independently within A. tuberculatus.

Screening of progeny derived from A. tuberculatus plants did not result in the identification of hybrids. Similar levels of fecundity were reported in crosses between A. tuberculatus and A. palmeri, with low hybrid frequency (Franssen et al. 2001). Furthermore, many seeds produced by Franssen and others were attributed to the rare 'partially monoecious' plants observed within their experiment, hereafter referred to as 'autopollination' (Franssen et al. 2001). In A. tuberculatus, 
245 gender is determined by a single loci, where males are heterogametic (Montgomery et al. 2019).

246 Therefore, pollen contamination is expected to result in a 1:1 ratio of male to female progeny,

247 whereas seed derived from autopollination would result in completely female progeny. Indeed, we

248 observed a skew towards female progeny when $A$. tuberculatus was allowed to cross only with $A$.

249 albus (Table 3). We suspect that male progeny were obtained as a result of pollen contamination.

251 Apomixis also has been suggested to explain seed production observed in isolated A. palmeri

252 females (Ribeiro et al. 2014). Indeed, apomixis would produce the same gender ratio (all females)

253 as expected due to autopollination. Dioecy can be viewed as a limiting factor for the colonization

254 of a new region. As A. tuberculatus is noted as an exceptional colonizer, a mechanism to overcome

255 the limitations of dioecy may not be unexpected. However, the mechanism through which seed

256 production is mediated is impactful for a developing population. Genetic segregation would be

257 expected under the autopollination hypothesis, which would result in diverse progeny. In contrast,

258 each progeny produced through the apomixis hypothesis would be genetically identical. A

259 mechanism that promotes genetic segregation may be advantageous towards adaptation to new

260 environments. Indeed, testing these hypotheses is straightforward: a heterozygous marker under

261 isolation should not segregate under apomixis, but should segregate under autopollination.

262 Preliminary attempts to identify a heterozygous loci within the selected parent plants of this study

263 were not successful.

265 There are benefits and costs associated with interspecific hybridization (Chunco 2014). An

266 invading species can rapidly gain access to adaptation traits to the new habitat, or the mixture

267 produced could be less fit than either parent. As the range of A. tuberculatus continues to expand, 
268 fundamental questions remain. Is this expansion, and subsequent displacement of native species,

269 mediated wholly through the genetic variation within the species, or obtained from outside gene

270 flow between species? While molecular surveys provide insight into these questions, the

271 hypotheses must then be experimentally examined. Here, we conclude that hybridization between

272 A. tuberculatus and A. albus can happen, though at a notably low frequency in comparison to other

273 interspecific crosses within the genus. Furthermore, due to sterility or near-sterility observed in

274 both the initial hybrids and their progeny, widescale introgression of A. albus into A. tuberculatus

275 seems unlikely in naturalized conditions. Theoretically, however, herbicide regimes within

276 production agriculture could generate a sufficient selection pressure for novel herbicide-resistance

277 traits, driving gene introgression between the species.

278

279 Acknowledgements

280 We thank Dr. A Lane Rayburn for help with flow cytometry.

281

282 
bioRxiv preprint doi: https://doi org/10.1101/2021.06.11.448086; this version posted June 11, 2021. The copyright holder for this preprint

283 Declarations

284 Funding

285 No funding was received for conducting this study.

286

287 Conflicts of interest

288 The authors have no relevant financial or non-financial interests to disclose.

289

290 Ethics approval

291 Not applicable.

292

293 Consent to participate

294 Not applicable.

295

296 Consent for publication

297 All authors consent to this research being published.

298

299 Availability of data and material

300 Datasets and material used or generated during the current study are available from the 301 corresponding author on reasonable request.

302

303 Code availability

304 Not applicable.

305 
bioRxiv preprint doi: https://doi.org/10.1101/2021.06.11448086; this version posted June 11, 2021. The copyright holder for this preprint (which was not certified by peer review) is the author/funder, who has granted bioRxiv a license to display the preprint in perpetuity. It is made available under aCC-BY-NC-ND 4.0 International license.

306 Authors' contributions

307 Patrick J Tranel conceived the study. Material preparation and data collection were performed by

308 Laura A Chatham, Danielle M McCormick, and Brent P Murphy. The first draft of the manuscript

309 was written by Brent P Murphy. All authors read and approved the final manuscript. 
References

Arnold ML (2004) Transfer and origin of adaptations through natural hybridization: were Anderson and Stebbins right? Plant Cell 16:562-570

Benbrook CM (2016) Trends in glyphosate herbicide use in the United States and globally. Environ Sci Eur 28:3

Chunco AJ (2014) Hybridization in a warmer world. Ecol Evol 4:2019-2031

Costea M, Weaver SE, Tardif FJ (2005) The biology of invasive alien plants in Canada. 3. Amaranthus tuberculatus (Moq.) Sauer var. rudis (Sauer) Costea \& Tardif. Can J Plant Sci $85: 507-522$

Culpepper AS, Grey TL, Vencill WK, et al (2006) Glyphosate-resistant Palmer amaranth (Amaranthus palmeri) confirmed in Georgia. Weed Sci 54:620-626

Franssen AS, Skinner DZ, Al-Khatib K, et al (2001) Interspecific hybridization and gene flow of ALS resistance in Amaranthus species. Weed Sci 49:598-606

Grant WF (1959) Cytogenetic studies in Amaranthus.: III. Chromosome numbers and phylogenetic aspects. Can J Genet Cytol 1:313-328

Heap I The International Survey of Herbicide Resistant Weeds. http://weedscience.org/. Accessed 21 May 2020

Kreiner JM, Giacomini DA, Bemm F, et al (2019) Multiple modes of convergent adaptation in the spread of glyphosate-resistant Amaranthus tuberculatus. Proc Natl Acad Sci USA 116:21076-21084

Milani A, Scarabel L, Sattin M (2020) A family affair: resistance mechanism and alternative control of three Amaranthus species resistant to acetolactate synthase inhibitors in Italy. Pest Manag Sci 76:1205-1213

Montgomery JS, Sadeque A, Giacomini DA, et al (2019) Sex-specific markers for waterhemp (Amaranthus tuberculatus) and Palmer amaranth (Amaranthus palmeri). Weed Sci 67:412418

Murphy BP, Larran AS, Ackley B, et al (2019) Survey of glyphosate-, atrazine- and lactofen resistance mechanisms in Ohio waterhemp (Amaranthus tuberculatus) populations. Weed Sci 67:296-302

Nandula VK, Wright AA, Bond JA, et al (2014) EPSPS amplification in glyphosate-resistant spiny amaranth (Amaranthus spinosus): a case of gene transfer via interspecific hybridization from glyphosate-resistant Palmer amaranth (Amaranthus palmeri). Pest Manag Sci 70:1902-1909 
Nie H, Mansfield BC, Harre NT, et al (2019) Investigating target-site resistance mechanism to the PPO-inhibiting herbicide fomesafen in waterhemp and interspecific hybridization of Amaranthus species using next generation sequencing. Pest Manag Sci 75:3235-3244

Oliveira MC, Gaines TA, Patterson EL, et al (2018) Interspecific and intraspecific transference of metabolism-based mesotrione resistance in dioecious weedy Amaranthus. Plant J 96:10511063

Patzoldt WL, Tranel PJ (2007) Multiple ALS mutations confer herbicide resistance in waterhemp (Amaranthus tuberculatus). Weed Sci 55:421-428

Patzoldt WL, Tranel PJ, Hager AG (2005) A waterhemp (Amaranthus tuberculatus) biotype with multiple resistance across three herbicide sites of action. Weed Sci 53:30-36

Rayburn AL, McCloskey R, Tatum TC, et al (2005) Genome size analysis of weedy Amaranthus species. Crop Sci 45:2557-2562

Ribeiro DN, Pan Z, Duke SO, et al (2014) Involvement of facultative apomixis in inheritance of EPSPS gene amplification in glyphosate-resistant Amaranthus palmeri. Planta 239:199212

Sauer JD (1967) The grain amaranths and their relatives: A revised taxonomic and geographic survey. Ann Mo Bot Gard 54:103-137

Steckel LE, Sprague CL, Stoller EW, Wax LM (2004) Temperature effects on germination of nine Amaranthus species. Weed Sci 52:217-221

Stetter MG, Schmid KJ (2017) Analysis of phylogenetic relationships and genome size evolution of the Amaranthus genus using GBS indicates the ancestors of an ancient crop. Mol Phylogenet Evol 109:80-92

Suarez-Gonzalez A, Lexer C, Cronk QCB (2018) Adaptive introgression: a plant perspective. Biol Lett 14:20170688

Tranel PJ, Riggins CW, Bell MS, Hager AG (2011) Herbicide resistances in Amaranthus tuberculatus: A call for new options. J Agric Food Chem 59:5808-5812

Trucco F, Jeschke MR, Rayburn AL, Tranel PJ (2005) Amaranthus hybridus can be pollinated frequently by $A$. tuberculatus under field conditions. Heredity 94:64-70

Trucco F, Tatum T, Rayburn AL, Tranel PJ (2009) Out of the swamp: unidirectional hybridization with weedy species may explain the prevalence of Amaranthus tuberculatus as a weed. New Phytol 184:819-827

Trucco F, Tranel PJ (2011) Amaranthus. In: Kole C (ed) Wild crop relatives: genomic and breeding resources: Vegetables. Springer, Berlin, Heidelberg, pp 11-21 
bioRxiv preprint doi: https://doi.org/10.1101/2021.06.11448086; this version posted June 11, 2021. The copyright holder for this preprint (which was not certified by peer review) is the author/funder, who has granted bioRxiv a license to display the preprint in perpetuity. It is made available under aCC-BY-NC-ND 4.0 International license.

376 Ward SM, Webster TM, Steckel LE (2013) Palmer amaranth (Amaranthus palmeri): A review.

$377 \quad$ Weed Technol 27:12-27

378 Wetzel DK, Horak MJ, Skinner DZ (1999) Use of PCR-based molecular markers to identify weedy

379 Amaranthus species. Weed Sci 47:518-523

380 
bioRxiv preprint doi: https://doi.org/10.1101/2021.06.11.448086; this version posted June 11, 2021. The copyright holder for this preprint (which was not certified by peer review) is the author/funder, who has granted bioRxiv a license to display the preprint in perpetuity. It is made available under aCC-BY-NC-ND 4.0 International license.

381 Figure 1: Confirmation of hybrids using restriction fragment length polymorphisms between the 382 parental species. Band order: undigested, DdeI, XhoI.

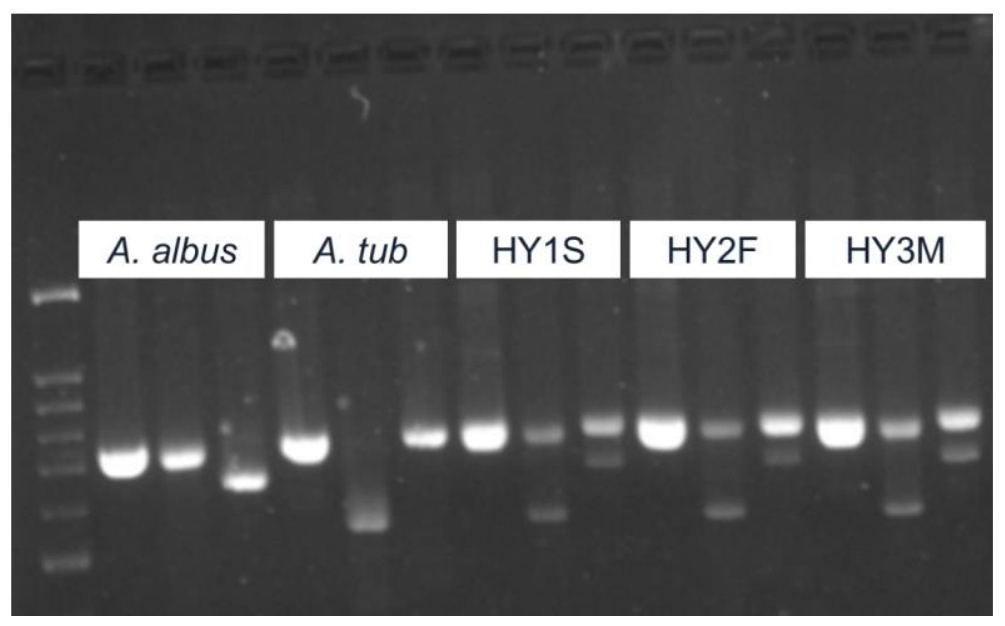


bioRxiv preprint doi: https://doi.org/10.1101/2021.06.11448086; this version posted June 11, 2021. The copyright holder for this preprint (which was not certified by peer review) is the author/funder, who has granted bioRxiv a license to display the preprint in perpetuity. It is made available under aCC-BY-NC-ND 4.0 International license.

384 Table 1: Amaranthus species-specific digest patterns for the internal transcribed spacer region $(+$,

385 restriction site present; -, restriction site absent).

\begin{tabular}{lcc}
\hline Species & DdeI & XhoI \\
\hline A. albus & $-/-$ & $+/+$ \\
A. tuberculatus & $+/+$ & $-/-$ \\
Hybrid & $+/-$ & $+/-$ \\
\hline
\end{tabular}

386 
bioRxiv preprint doi: https://doi org/10.1101/2021.06.11.448086; this version posted June 11, 2021. The copyright holder for this preprint (which was not certified by peer review) is the author/funder, who has granted bioRxiv a license to display the preprint in perpetuity. It is made available under aCC-BY-NC-ND 4.0 International license.

388 Table 2: DNA content of $\mathrm{BC}_{1}$ individuals derived from hybrid $\mathrm{HY} 2 \mathrm{~F}$ x Amaranthus tuberculatus.

Sample $\quad$ pg DNA 2N ${ }^{-1}$

\section{$\underline{\text { Parent controls }}$}

A. albus $\quad 1.18$

A. tuberculatus $\quad 1.42$

$\underline{\mathrm{BC}}_{1} \underline{\text { individuals }}$

HY1 1.78

HY3 1.85

HY5 1.73 
bioRxiv preprint doi: https://doi org/10.1101/2021.0611.448086; this version posted June 11, 2021. The copyright holder for this preprint (which was not certified by peer review) is the author/funder, who has granted bioRxiv a license to display the preprint in perpetuity. It is made available under aCC-BY-NC-ND 4.0 International license.

391 Table 3: Gender ratios of progeny from Amaranthus tuberculatus females grown in the presence

392 of Amaranthus albus as a pollen source.

\begin{tabular}{lccc}
\hline Female & \multicolumn{2}{c}{ Progeny } & P-value $^{\mathrm{a}}$ \\
\cline { 2 - 3 } & Male & Female & \\
\hline ACR10 & 1 & 5 & 0.102 \\
ACR20 & 9 & 36 & $<0.001$ \\
ACR3-5 & 2 & 21 & $<0.001$ \\
ACR3-1 & 4 & 42 & $<0.001$ \\
Control $^{\mathrm{b}}$ & 29 & 28 & 0.894
\end{tabular}

$393{ }^{a}$ Chi-square test was conducted against an expected 1:1 male:female ratio.

394 bandom subset of progeny of an A. tuberculatus x A. tuberculatus cross. 
bioRxiv preprint doi: https://doi.org/10.1101/2021.06.11.448086; this version posted June 11, 2021. The copyright holder for this preprint (which was not certified by peer review) is the author/funder, who has granted bioRxiv a license to display the preprint in perpetuity. It is made available under aCC-BY-NC-ND 4.0 International license.

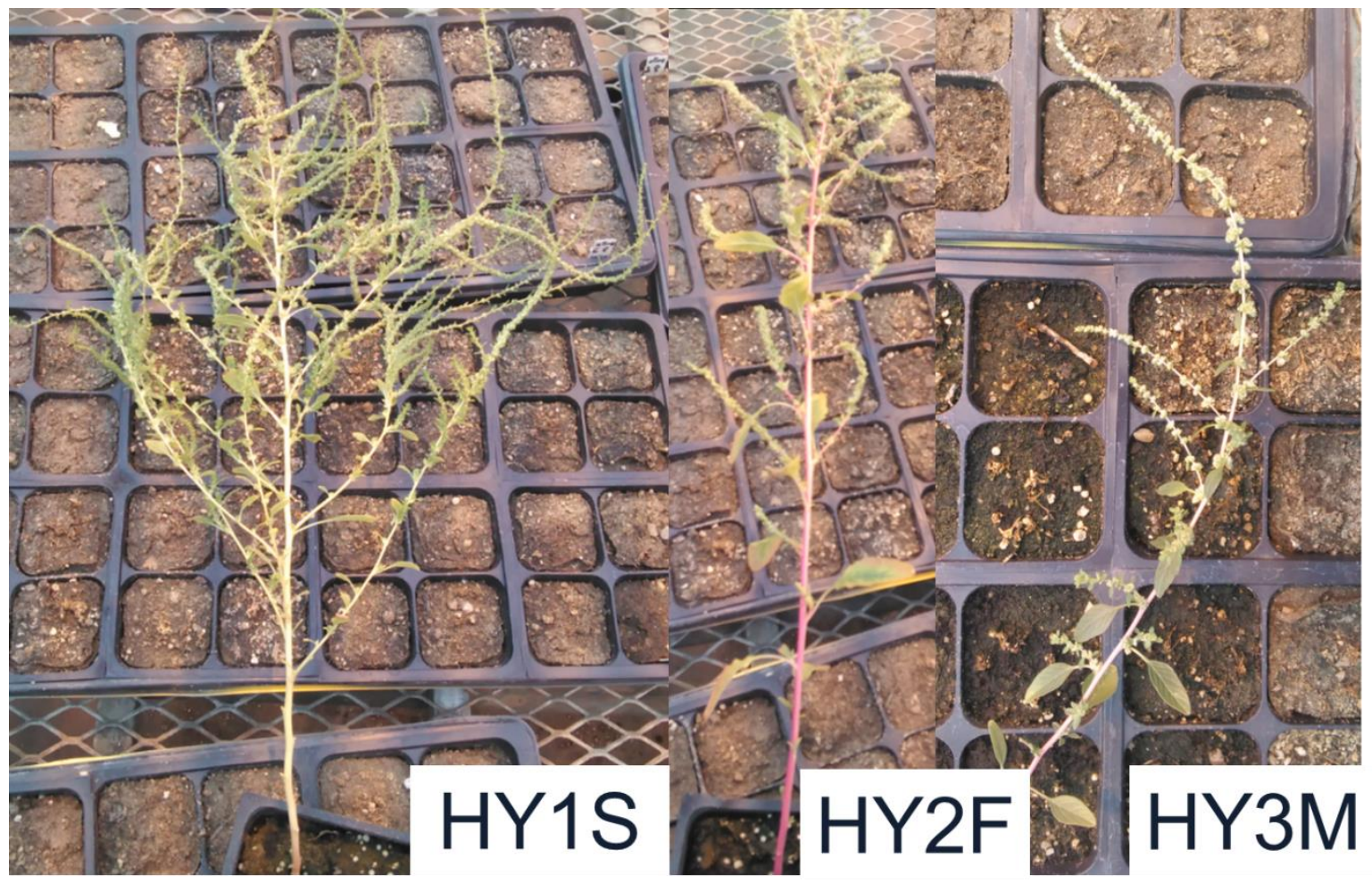

399 Supplementary Figure 1: Morphology of Amaranthus. albus x Amaranthus tuberculatus hybrids. 
bioRxiv preprint doi: https://doi.org/10.1101/2021.06.11.448086; this version posted June 11, 2021. The copyright holder for this preprint (which was not certified by peer review) is the author/funder, who has granted bioRxiv a license to display the preprint in perpetuity. It is made available under aCC-BY-NC-ND 4.0 International license.
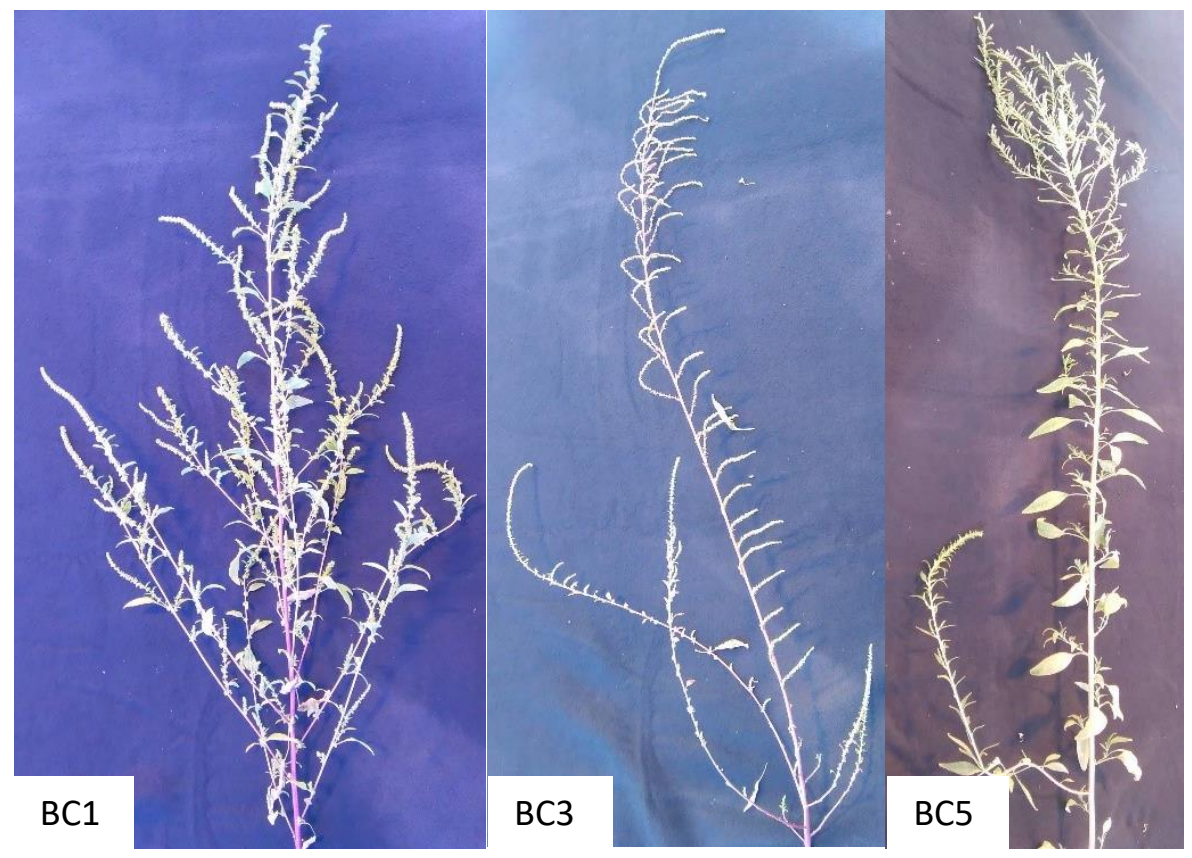

403 Supplementary Figure 2: Morphology of backcross [HY2F (see Supplementary Figure 1) $\mathrm{x}$ 404 Amaranthus tuberculatus] progeny. A, HY1; B, HY3; C, HY5. 